\title{
Escherichia coli tolQ Mutants Are Resistant to Filamentous Bacteriophages That Adsorb to the Tips, not the Shafts, of Conjugative Pili
}

\author{
By DAVID E. BRADLEY* AND JEANETTE WHELAN \\ Faculty of Medicine, Memorial University of Newfoundland, St John's, Newfoundland, \\ Canada A1B 3 V6
}

(Received 3 January 1989; revised 21 March 1989; accepted 12 April 1989)

The tolQ (previously fii) mutation in Escherichia coli $\mathrm{K} 12$ inhibits infection by filamentous bacteriophages $\mathrm{f} 1$ and IKe but not by RNA-containing phage $\mathrm{f} 2$. This work extends these observations to other plasmid-specific bacteriophages including various filamentous, RNAcontaining, and lipid-containing isolates. Only tip-adsorbing filamentous phages were affected by $t o l Q$ and not shaft-adsorbing ones. Electron microscopy showed that RP4-specific filamentous phage Pf3 was one of the latter kind. Several tip-adsorbing filamentous phages inhibited conjugation between tolQ strains carrying their specific plasmids, implicating the phage receptors (conjugative pili) as mating organelles. tolQ mutant strains were as proficient as their parents in conjugation mediated by a wide range of plasmids.

\section{INTRODUCTION}

Plasmid-specific filamentous and RNA-containing bacteriophages of Escherichia coli adsorb to conjugative pili (Bradley, 1967; Marvin \& Hohn, 1969). Most filamentous phages attach to the pilus tips, but a few isolates, together with all RNA phages, adsorb to the pilus shafts (sides). Sun \& Webster (1986) described a mutation, fii, which caused the inhibition of infection of $\mathrm{F}^{+}$ bacteria by filamentous bacteriophage $\mathrm{f} 1$, but not by RNA-containing phage $\mathrm{f} 2$. Similarly, the mutation inhibited the infection of bacteria harbouring plasmids of incompatibility group $\mathbf{N}$ (IncN) by filamentous phage IKe. The fii mutation also provided tolerance against $\mathrm{E}$ colicins, which are classified as low- $M_{\mathrm{r}}$ bacteriocins, as opposed to high- $M_{\mathrm{r}}$ bacteriocins of bacteriophage origin (Bradley, 1967). Sun \& Webster (1987) sequenced the fii region, and renamed the mutation for filamentous phage inhibition tolQ. The entire gene cluster, $t o l Q R A B$, encodes proteins which form a transport system across the bacterial envelope for large molecules. The main purpose of this work has been to extend the observations of Sun \& Webster (1986) to the additional plasmid-specific bacteriophages in our collection. Furthermore, the hypothesis that plasmid DNA transfer in conjugation (see Willetts \& Wilkins, 1984) might be affected by $t o l Q$ has been tested.

The inhibition of $\mathrm{F}$ plasmid transfer by the presence in mating mixtures of inactivated pilusspecific filamentous bacteriophages demonstrated unequivocally that $\mathrm{F}$ pili were involved in conjugation (Ippen \& Valentine, 1967; Novotny et al., 1968). Similar experiments have been done here with filamentous phages specific for plasmids other than F. The presence of the tolQ mutation rather than phage inactivation was used to prevent infection of donor strains.

\section{METHODS}

Strains, bacteriophages and plasmids. The parent strain used by Sun \& Webster (1986) was E. coli K 12 P90C [ara $\Delta$ (lac pro) thi]. Their strain GM1 was P90C/F'lac pro. The tolQ (=fii-1) derivative of GM1 was TPS13. For this work we cured GM1 and TPS13 of the F'lac pro plasmid by overnight growth in broth containing novobiocin $\left(150 \mu \mathrm{g} \mathrm{ml}^{-1}\right)$; $\mathrm{Lac}^{-}$colonies were then sought on MacConkey agar; plasmid loss was checked by agarose gel electrophoresis. Cured GM1 (= P90C) was designated P90C; cured TPS13 (= P90CtolQ) was designated TPS. 
Nalidixic acid- and rifampicin-resistant derivatives of both strains $\left(\mathrm{Nal}^{\mathrm{R}}, \mathrm{Rif}^{\mathrm{R}}\right.$; suffix -1 and -2 respectively) were isolated. In addition to phage fd, tolerance to colicin $\mathrm{E} 1$ was used to check the tolQ phenotype. A loopful of $E$. coli $\mathrm{K} 12$ strain E8705(ColE1 ::Tn7) was suspended in $2 \mathrm{ml}$ broth and about $10 \mu \mathrm{l}$ of this suspension was spotted on the tol $Q$ strain (see spot test for phages below); after incubation, lack of clearing around the bacterial overgrowth indicated tolerance. Strains JE2571 (lac leu thr str fla pil) and J53 (Lac ${ }^{+}$pro met) or their $\mathrm{Nal}^{\mathrm{R}}$ or Rif ${ }^{\mathrm{R}}$ derivatives were used as plasmid hosts.

Bacteriophages and references are listed in Table 1. Most known filamentous phages were used with the exception of SF (Coetzee et al., 1986), which was an fd-like phage with an extended host range, but is no longer available. The two filamentous phages Ifl (Meynell \& Lawn, 1968) and PR64 (abbreviated from PR64FS; Coetzee et al., 1980) adsorb to the thin flexible pili as opposed to the thick rigid pili of I complex plasmids (Bradley, 1984). Since they are serologically related (Coetzee et al., 1982) we used only PR64. We could not test the only other filamentous phage known to adsorb to the pilus shaft, C-2 (Bradley et al., 1982a), since it only infected Salmonella typhimurium strains carrying transfer-derepressed IncC plasmids, not similar $E$. coli $\mathrm{K} 12$ strains.

Plasmids were selected on the basis of availability and for good responses to plasmid-specific phages with host strain P90C; most are cited by Jacob et al. (1977) with the exceptions of EDP208 (transfer-derepressed $\mathrm{F}_{0} l a c$ mutant constructed by N. Willetts; see Worobec et al., 1983), which is IncSI (Coetzee et al., 1986), pMG110 (IncHII; Wolfson et al., 1982), pIN25 (isolated by S. B. Levy; see Bradley \& Whelan, 1985), pAr-32 (Bradley et al., 1982b) and R687 (IncD; see Datta, 1979). Strain TPS-2(R687) gave poor clearing in spot tests with phage fd, so the plasmid could not be used in some experiments.

Media, bacteriophage techniques and mating methods. Brain Heart Infusion broth or agar (BBL) was used for most cultures. The minimal salts medium used was M9, and drug concentrations were as listed by Bradley (1984).

Methods for phage growth, and the spot test for phage activity, were as described or cited in Bradley (1967). Filamentous phages were grown using strain JE2571 harbouring the appropriate plasmid. Brain Heart Infusion broth was inoculated with bacteria and phage, then grown statically overnight at $37^{\circ} \mathrm{C}\left(30^{\circ} \mathrm{C}\right.$ for phages $\mathrm{tf}-1$, $t$, and pilH $\alpha$ ). After removing bacteria by several cycles of centrifugation (filtration removes filamentous phage virions and is unsuitable), the suspension was titrated by spotting $10 \mu \mathrm{l}$ samples of serial dilutions on a soft agar layer plate of the host strain, and counting plaques after incubation. Mating methods were as described previously (Bradley et al., 1980; Bradley, 1984).

Electron microscopy. Techniques were those previously employed (Bradley et al., 1981 $a, b, c$ ).

\section{RESULTS}

\section{Effect of tolQ mutation on infection by plasmid-specific bacteriophages}

As many plasmid-specific bacteriophages as possible, including filamentous, RNAcontaining, and lipid-containing types were tested for inhibition of infection by the tolQ mutation. Results obtained with spot tests for lytic activity, together with the locations of the phage adsorption sites on their conjugative pilus receptors, are given in Table 1 . In agreement with the results of Sun \& Webster (1986), it was found that filamentous phage fd infected the $\mathrm{TolQ}^{+}$strain P90C-2(F::Tn5) but not its tolQ derivative TPS-2(F::Tn5), and that RNAcontaining phage of $\mathrm{Q} \beta$ infected both strains. Similar results were obtained with $\mathrm{R} 1 d r d 19$ (IncFII) and EDP208 (IncS); the RNA phage $F_{0}$ lac (Bradley et al., 1981c) replaced Q $\beta$ for the latter. The tolQ mutation in strain TPS-2(N3) also inhibited infection by the IncN-specific filamentous phage IKe (in agreement with Sun \& Webster, 1986). Filamentous phages PR64 (specific for I complex plasmids) and X-2 (IncX-specific) were also inhibited. Three other filamentous phages, $\mathrm{Pf} 3, \mathrm{tf}-1$, and $\mathrm{X}$, together with all non-filamentous phages, were not.

\section{Effect of tolQ mutation on plasmid transfer}

A series of plasmids selected by incompatibility grouping and pilus type was tested for inhibition of transfer from JE2571 or J53 to tolQ strains TPS-1 or -2 . The following transferderepressed plasmids with surface-obligatory conjugation systems (exceptions RIdrd19 and pIN25) were tested by cross-streak mating (Bradley et al., 1980): R1drd19 (IncFII), N3 (IncN), RP4 (IncP), pIN25 (IncT), pAr-32 (IncU), R905 (IncV), Sa (IncW). Quantitative broth matings were used for R453 (IncFI), R478 (IncHI2), MIP233 (HI3), R144 (IncI 1 + B), R391 (IncJ), , F lac (IncSI) and quantitative plate matings for RIP64 (IncC), R687 (IncD), pMG110 (IncHII), RIP69 (IncM) and TP228 (IncX). A significantly lower transfer frequency with recipients TPS-1 or -2 compared with recipients $\mathrm{P} 90 \mathrm{C}-1$ or -2 was not detected with any plasmid. The possibility 
Table 1. Inhibition of plasmid-specific bacteriophage infection by tolQ mutation

\begin{tabular}{|c|c|c|c|c|c|c|c|}
\hline \multirow[b]{2}{*}{ Phage } & \multirow[b]{2}{*}{ Type } & \multirow{2}{*}{$\begin{array}{l}\text { Adsorption } \\
\text { site on pili }\end{array}$} & \multirow[b]{2}{*}{ Plasmid } & \multirow[b]{2}{*}{ Inc } & \multicolumn{2}{|c|}{$\begin{array}{c}\text { Phage sensitivity } \\
\text { of plasmid host } \\
\text { strain* }\end{array}$} & \multirow[b]{2}{*}{ Reference for phage } \\
\hline & & & & & P90C-2 & TPS- 2 & \\
\hline fd & Filamentous & Tip & $F:: \operatorname{Tn} 5$ & FI & + & - & Marvin \& Hohn (1969) \\
\hline $\mathrm{Q} \beta$ & RNA & Shaft & $\mathrm{F}:: \operatorname{Tn} 5$ & FI & + & + & Watanabe (1964) \\
\hline fd & Filamentous & Tip & $\mathrm{R} 1 d r d 19$ & FII & + & - & Marvin \& Hohn (1969) \\
\hline $\mathrm{Q} \beta$ & RNA & Shaft & $\mathrm{R} 1 d r d 19$ & FII & + & + & Watanabe (1964) \\
\hline fd & Filamentous & Tip & EDP208 & $\mathbf{S}$ & + & - & Marvin \& Hohn (1969) \\
\hline $\mathrm{F}_{0} l a c$ & RNA & Shaft ${ }^{+}$ & EDP208 & $\mathbf{S}$ & + & $(+)$ & Bradley et al. $(1981 c)$ \\
\hline PR64 & Filamentous & Tip $\ddagger$ & R163drd7 & $\mathrm{I}_{1}+\mathrm{B}$ & + & - & Coetzee et al. (1980) \\
\hline $\mathrm{I} \alpha$ & RNA & Shaft $\ddagger$ & $\mathrm{R} 163 d r d 7$ & $\mathrm{I}_{1}+\mathrm{B}$ & + & + & Coetzee et al. (1982) \\
\hline IKe & Filamentous & Tip & N3 & $\mathbf{N}$ & + & - & Khatoon et al. (1972) \\
\hline PR4 & Lipid & Tip & N3 & $\mathbf{N}$ & + & + & Stanisich (1974) \\
\hline Pf3 & Filamentous & Shaft $\S$ & RP4 & $\mathbf{P}$ & + & + & Stanisich (1974) \\
\hline PR4 & Lipid & Tip & RP4 & $\mathbf{P}$ & + & + & Stanisich (1974) \\
\hline tf-1 & Filamentous & Shaft $\dagger$ & pIN25 & $\mathrm{T}$ & + & + & Coetzee et al. (1987) \\
\hline $\mathrm{t}$ & RNA & Shaft ${ }^{\dagger}$ & pIN25 & $\mathrm{T}$ & + & $(+)$ & Bradley et al. $(1981 b)$ \\
\hline PR4 & Lipid & Tip & $\mathrm{Sa}$ & W & + & + & Stanisich (1974) \\
\hline $\mathbf{X}$ & Filamentous & Tip & R6K & $\mathbf{X}$ & $(+)$ & $(+)$ & Bradley et al. (1981a) \\
\hline$X-2$ & Filamentous & Unknown§ & R6K & $\mathbf{X}$ & + & - & Coetzee et al. (1988) \\
\hline pilH $\alpha$ & RNA & Shaft & pMG110 & HII & $(+)$ & $(+)$ & Coetzee et al. (1985) \\
\hline
\end{tabular}

* Using the spot test for sensitivity to bacteriophages (see Methods): + , complete or slightly hazy clearing; $(+)$, hazy but definite clearing; - , no visible clearing.

† Adsorption limited to the tapered region of the pilus shaft near the pointed tip; virions do not attach to the point itself.

$\ddagger$ IncI $_{1}+$ B plasmids encode thin flexible and thick rigid pili (Bradley, 1984). Phages PR64 (= PR64FS) and I $\alpha$ adsorb to the thin pili, which stabilize mating aggregates, thick pili mediating DNA transfer.

$\S$ The adsorption site of Pf 3 on the P pilus was not known so was determined for this study as being on the shaft (sides) of the pilus (see Results). Attempts to visualize phage X-2 virions attached to $X$ pili were unsuccessful (Coetzee et al., 1988).

that $t o l Q$ prevented plasmid entry was therefore eliminated. In view of these results, and because of the nature of the conjugation mechanism (Willetts \& Wilkins, 1984), it seemed highly unlikely that plasmid exit from tol $Q$ donor strains would be prevented by the mutation. Sun \& Webster (1986) found that TPS13 functioned normally as a donor for plasmid F, and their equivalent of TPS-2(N3) for N3. While a complete series of transfer tests from TPS strains was not carried out, a few examples are given in Table 2, where matings were done for another purpose.

\section{Inhibition of plasmid transfer between tolQ strains by filamentous phages}

The effect of various filamentous phages on plasmid transfer frequencies (see Introduction) was assessed by determining the percentage reduction obtained (inhibition) using the plasmidspecific phage with reference to a non-specific filamentous phage control (Table 2). Repressed plasmids (determining few pili) were employed to avoid having too many receptors which might have used up all the phage virions, exceptions being $\mathrm{F}:: \mathrm{Tn} 5$ (only determined about one pilus per cell) and N3 (pili detatch in a liquid; Bradley et al., 1980). In all cases with over $90 \%$ inhibition, the pilus receptors were clearly implicated as mating organelles. The $45 \%$ inhibition obtained with phage IKe and thick $\mathrm{I}_{2}$ pili was considered inconclusive and probably reflected a poor adsorption efficiency. Frequencies of $<1.0 \times 10^{-4}$ transconjugants per donor $\mathrm{h}^{-1}$ were approximate, an example being the negative inhibition obtained with phage X-2 and IncX plasmid TP231. These frequencies were a mean of three matings (two with Tc, one with $\mathrm{Cm}$ selection) and indicate no effect on plasmid transfer by phage $X-2$. The value of $-19 \%$ reflects the inaccuracy of mating techniques at low frequencies since it is clear that X-2 could not enhance mating. 
Table 2. Plasmid transfer from TPS-2 in the presence of tip-adsorbing filamentous phages

All matings were done in liquid nutrient using strain TPS-1 as recipient and nalidixic acid counterselection against TPS-2 donor strains.

Phages in mating mixture

$\overbrace{\text { Test phage } \text { Control phage }}^{\text {(titre p.f.u. } \mathrm{ml}^{-1} \text { ) }}$

\section{Pilus Donor}

type* plasmid

fd $\left(10^{12}\right)$

fd $\left(10^{12}\right)$

fd $\left(10^{12}\right)$

PR64 $\left(10^{8}\right)$

PR64 $\left(10^{8}\right)$

IKe $\left(10^{9}\right)$

IKe $\left(10^{9}\right)$

$\mathrm{X}-2\left(10^{10}\right)$

$\begin{array}{ccc}\text { F } & \text { F::Tn5 } & \text { Km } \\ \text { D } & \text { R687\| } & \text { Km } \\ \text { S } & \text { F }_{0} l a c & \text { Lac } \\ I_{1} \mathrm{f} & \text { R144 } & \text { Km } \\ \mathrm{I}_{2} \mathrm{f} & \text { R721 } & \text { Tp } \\ \mathrm{I}_{2} \mathrm{r} & \text { R721 } & \text { Tp } \\ \text { N } & \text { N3ף } & \text { Tc } \\ \text { X } & \text { TP231 } & \text { Tc, Cm }\end{array}$

Transfer frequency $\ddagger$ with

$\begin{array}{rcr}\text { Test phage } & \text { Control phage } & \begin{array}{c}\text { Inhibition§ } \\ (\%)\end{array} \\ 1.0 \times 10^{-3} & 6.1 \times 10^{-2} & 98 \\ 2.2 \times 10^{-6} & 2.6 \times 10^{-5} & 92 \\ 4.9 \times 10^{-8} & 1.4 \times 10^{-6} & 97 \\ <6.9 \times 10^{-8} & 1.3 \times 10^{-5} & >100 \\ <4.3 \times 10^{-8} & 8.3 \times 10^{-5} & >100 \\ 6.1 \times 10^{-5} & 1.1 \times 10^{-4} & 45 \\ 1.1 \times 10^{-5} & 3.6 \times 10^{-4} & 97 \\ 3.1 \times 10^{-5} & 2.6 \times 10^{-5} & -19\end{array}$

* Correspond to incompatibility groups F, D, S, N, X and I complex. The latter plasmids determine both thin flexible (f) and rigid (r) pili (Bradley, 1984).

† Plasmid selection: Cm, chloramphenicol; Km, kanamycin; Lac, lactose (M9 medium); Tc, tetracycline; Tp, trimethoprim. For concentrations see Bradley (1984).

$\ddagger$ Transconjugants per donor $h^{-1}$. The test phage was specific for the pilus type indicated, whereas the control phage was not. Both were made similarly from strain JE2571 carrying the appropriate plasmids. Where no transfer could be detected, $a^{\prime}<$ ' frequency was calculated assuming one colony on plates at the lowest dilution used $\left(10^{-1}\right)$.

$\S$ Frequency with the test phage expressed as a percentage of that with the control phage and subtracted from $100 \%$. For an explanation of the single negative inhibition found, see text.

|| TPS-2(R687) was resistant to phage fd although R687 normally confers sensitivity to K12 strains (D. E. Bradley, unpublished). Transfer frequencies were approximate due to the instability of IncD plasmids in $E$. coli $\mathrm{K} 12$.

I N3 is a derepressed surface-mating plasmid (Bradley et al., 1980) not inhibited for transfer by nalidixic acid. Surface mating occurred here on transconjugant-selecting plates at the low dilutions required to detect transfer frequencies in a liquid environment. Transconjugant colonies from a liquid mating are much larger than those from subsequent plate mating; the latter originate from bacteria having a shorter time to express drug resistance, and then to grow into colonies (D. E. Bradley, unpublished). Frequencies were obtained by counting the distinctive larger colonies.

\section{Adsorption site of filamentous phage Pf 3}

The only filamentous phage whose adsorption site on conjugative pili had not been previously studied was Pf3 (specific for IncP plasmids; Stanisich, 1974). Its infection was not inhibited by the mutation in tolQ. Electron microscopy showed that it attached along the pilus shaft (Fig. 1) and was not specific for the tip or any area close to it, as was the case for tf-1 (Coetzee et al., 1987). This explained why the tol $Q$ mutation did not affect it.

\section{DISCUSSION}

It is clear that the tolQ mutation only inhibits infection by tip-adsorbing, not shaft-adsorbing filamentous phages, an exception being phage $X$. This virus appears to adsorb precisely at the pilus tip (Bradley et al., 1981 a) and yet is not inhibited; only single virions are attached at this locus, multiple adsorption being expected if attachment is proximal from the tip. Phage $\mathrm{X}$ has a very wide plasmid specificity range, but it is not known whether this is connected with its insensitivity to the tolQ effect. Filamentous phage X-2 (IncX-specific), whose receptor was not identifiable due to poor adsorption (Coetzee et al., 1988), was also inhibited by tolQ; because of this, it seems very likely that it attaches to the tips of X pili. The inhibition of phage PR64 infection by $t o l Q$ is noteworthy. PR64 adsorbs to the tips of thin $\mathrm{I}_{1}$ or thin $\mathrm{I}_{2}$ pili, which act as 'grappling hooks' in conjugation, forming stable mating aggregates in a liquid. Cell-to-cell contact between outer membranes together with plasmid DNA transfer is believed to be mediated by rigid pili, the $I_{2}$ type being phage IKe receptors (see Bradley, 1984). Inhibition of 


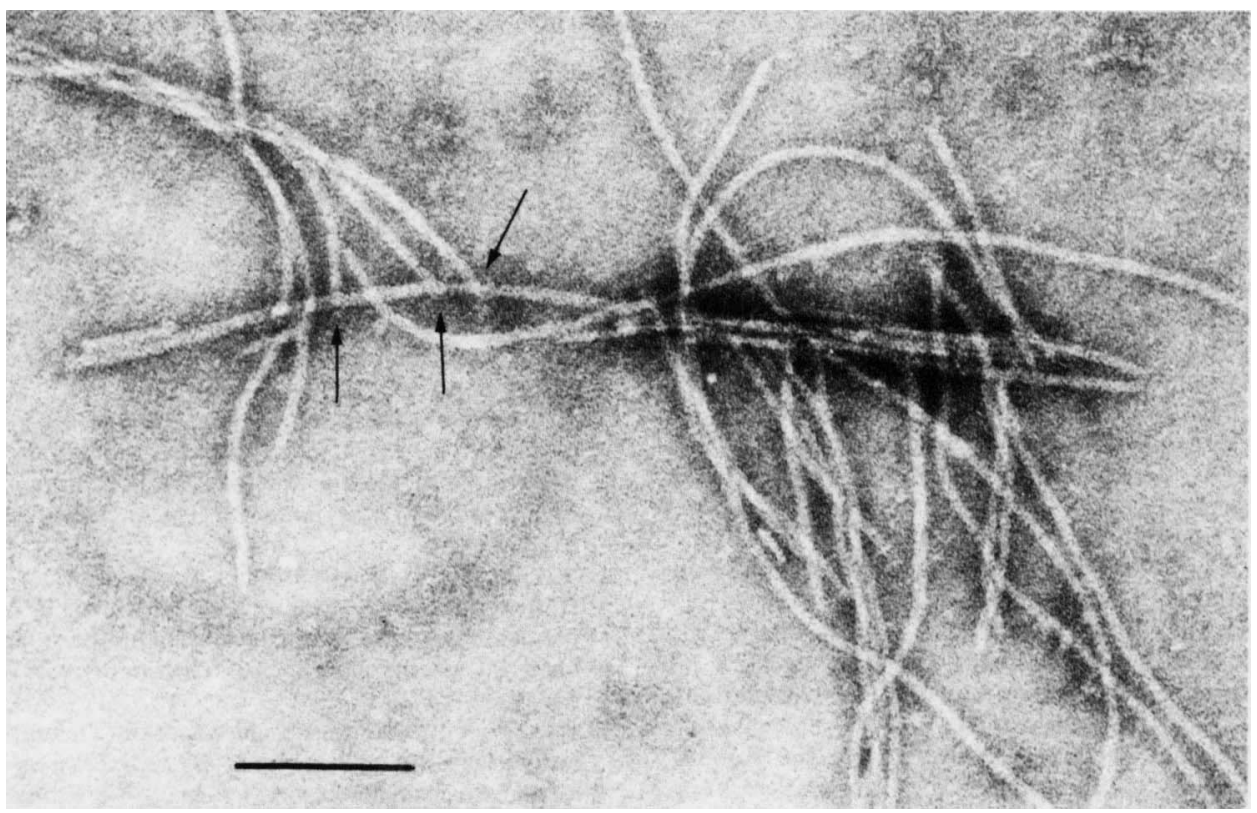

Fig. 1. IncP-specific filamentous phage Pf3 adsorbed to $P$ pili from strain JE2571(RP4) after 1 h. Points of attachment along the pilus shaft can be clearly seen (arrowed). Negatively stained; bar, $100 \mathrm{~nm}$.

phage PR64 infection suggests that these thin flexible pili may retract like thick flexible pili (see below).

The morphological type of pilus receptor, whether thick flexible (F, S, X), thin flexible (I complex), or rigid $(\mathrm{N})$, does not affect filamentous phage inhibition. Possibly, after a filamentous phage has adsorbed precisely to the conjugative pilus tip and the pilus has retracted, the virion is pulled through a molecular assembly in the outer membrane as if it was an additional part of the pilus. After the capsid is removed, probably in the periplasm, the DNA is further processed through the inner membrane by the $t o l Q R A B$ gene products. We suggest that, unless the phage attaches exactly at the pilus tip, it cannot be pulled through the outer membrane, so that a different transport mechanism would be required for the DNA of shaftadsorbing filamentous phages. Clearly phages with a larger profile like those containing RNA or lipid could not be pulled through the outer membrane either; indeed their modes of infection are quite different (Bradley, 1972, 1978; Silverman \& Valentine, 1969). The function of the tolQRAB gene products seems to be limited at present to the transport of tip-adsorbing filamentous phage DNA and E colicins across the bacterial envelope. The transport mechanism and natural function of the gene cluster might be easier to elucidate if other affected macromolecules could be identified.

We have used tolQ TPS strains as plasmid hosts to demonstrate mating inhibition by filamentous phages that adsorb to conjugative pilus tips. The pilus types that we have implicated as mating organelles in this way are $\mathrm{D}, \mathrm{S}$, thin $\mathrm{I}_{1}$, thin $\mathrm{I}_{2}$, and $\mathrm{N}$. The $\mathrm{F}$ pilus acted as a control since it has been tested in similar experiments (Ippen \& Valentine, 1967; Novotny et al., 1968). Other pili have been shown to be involved in conjugation using several different agents for specifically inhibiting mating. They are thin $\mathrm{I}_{1}$ (anti-pilus serum; Harden \& Meynell, 1972), W (inactivated lipid-phage; Bradley, 1978), the HI3 pili of plasmid MIP233 (anti-pilus serum; Bradley, 1986) and $\mathrm{N}$ and $\mathrm{P}$ pili (concentrated pilus preparations blocking receptors on recipient cells; Bradley \& Chaudhuri, 1980). We have thus confirmed the roles of thin $\mathrm{I}_{1}$ and $\mathrm{N}$ pili, and added $\mathrm{D}, \mathrm{S}$, and thin $\mathrm{I}_{2}$ pili.

We thank Dr S. P. Howard for suggesting this project and providing strains. The work was supported by the Medical Research Council of Canada (grant MT5608). 


\section{REFERENCES}

BRaDley, D. E. (1967). Ultrastructure of bacteriophages and bacteriocins. Bacteriological Reviews 31, 230-314.

Bradley, D. E. (1972). Shortening of Pseudomonas aeruginosa pili after RNA-phage adsorption. Journal of General Microbiology 72, 303-319.

BraDLEY, D. E. (1978). W pili: characteristics and interaction with lipid phages specific for N, P-1, and W group plasmids. In Pili, pp. 339-353. Edited by D. E. Bradley, E. Raizen, P. Fives-Taylor \& J. Ou. Washington, DC: International Conferences on Pili.

BraDLEY, D. E. (1984). Characteristics and function of thick and thin conjugative pili determined by transfer-derepressed plasmids of incompatibility groups $\mathrm{I}_{1}, \mathrm{I}_{2}, \mathrm{I}_{5}, \mathrm{~B}, \mathrm{~K}$ and $\mathrm{Z}$. Journal of General Microbiology 130, 1489-1502.

BRADLEY, D. E. (1986). The unique conjugation system of IncHI3 plasmid MIP233. Plasmid 16, 63-71.

Bradley, D. E. \& Chaudhuri, T. (1980). Characteristics and interaction with bacteriophages of pili determined by a plasmid of the $\mathrm{N}$ incompatibility group. In Plasmids and Transposons, Environmental Effects and Maintenance Mechanisms, pp. 335-342. Edited by C. Stuttard \& K. R. Rozee. New York: Academic Press.

Bradley, D. E. \& Whelan, J. (1985). Conjugation systems of IncT plasmids. Journal of General Microbiology 131, 2665-2671.

Bradley, D. E., Taylor, D. E. \& Cohen, D. R. (1980). Specification of surface mating systems among conjugative drug resistance plasmids in Escherichia coli K-12. Journal of Bacteriology 143, $1466-1470$.

Bradley, D. E., Coetzee, J. N., Bothma, T. \& Hedges, R. W. (1981a). Phage X: a plasmiddependent, broad host range, filamentous bacterial virus. Journal of General Microbiology 126, 389-396.

Bradley, D. E., Coetzee, J. N., Bothma, T. \& HeDGes, R. W. (1981 $b$ ). Phage t: a group T plasmiddependent bacteriophage. Journal of General Microbiology 126, 397-403.

Bradley, D. E., Coetzee, J. N., Bothma, T. \& Hedges, R. W. $(1981 c)$. Phage $\mathrm{F}_{0}$ lac: an $\mathrm{F}_{0}$ lac plasmid-dependent bacteriophage. Journal of General Microbiology 126, 405-411.

Bradley, D. E., Sirgel, F. A., Coetzee, J. N., Hedges, R. W. \& Coetzee, W. F. (1982a). Phages $\mathrm{C}-2$ and $\mathrm{J}$ : IncC and IncJ plasmid-dependent phages respectively Journal of General Microbiology 128, 2485-2498.

Bradley, D. E., Aoki, T., Kitao, T., Arai, T. \& TSCHÄPE, H. (1982b). Specification of characteristics for the classification of plasmids in incompatibility group U. Plasmid 8, 89-93.

Bradley, D. E., Coetzee, J. N. \& Hedges, R. W. (1983). IncI $\mathrm{I}_{2}$ plasmids specify sensitivity to filamentous phage IKe. Journal of Bacteriology 154, 505-507.

Coetzee, J. N., Sirgel, F. A. \& Lecatsas, G. (1980). Properties of a filamentous phage which adsorbs to pili coded by plasmids of the IncI complex. Journal of General Microbiology 117, 547-551.

Coetzee, J. N., Bradley, D. E. \& Hedges, R. W. (1982). Phages $I \alpha$ and $I_{2}-2$ : plasmid-dependent bacteriophages. Journal of General Microbiology 128 , 2797-2804.
Coetzee, J. N., Bradley, D. E., Fleming, J., DU Toit, L., Hughes, V. M. \& Hedges, R. W. (1985). Phage pilH $\alpha$ : a phage which adsorbs to IncHI and IncHII plasmid-coded pili. Journal of General Microbiology 131, 1115-1121.

Coetzee, J. N., Bradley, D. E., Hedges, R. W., Hughes, V. M., MCCONNELl, M. M., DU TOIT, L. \& TWEEHUYSEN, M. (1986). Bacteriophages $\mathrm{F}_{0} l a c h$, SR, SF: phages which adsorb to pili encoded by plasmids of the new S-complex. Journal of General Microbiology 132, 2907-2917.

Coetzee, J. N., Bradley, D. E., Hedges, R. W. \& TWeEhuizen, M. (1987). Phage tf- 1 : a filamentous bacteriophage specific for bacteria harbouring the IncT plasmid pIN25. Journal of General Microbiology 133, 953-960.

Coetzee, J. N., Bradley, D. E., du Toit, L. \& Hedges, R. W. (1988). Bacteriophage X-2: a filamentous phage lysing IncX-plasmid-harbouring bacterial strains. Journal of General Microbiology 134, 2535-2541.

DatTa, N. (1979). Plasmid classification: incompatibility grouping. In Plasmids of Medical, Environmental and Commercial Importance, pp. 3-12. Edited by K. N. Timmis \& A. Pühler. Amsterdam: Elsevier/ North-Holland Biomedical Press.

HaRden, V. \& MeYnell, E. (1972). Inhibition of gene transfer by antiserum and identification of serotypes of sex pili. Journal of Bacteriology 109, 1067-1074.

IPPEN, K. A. \& VALENTINE, R. C. (1967). The sex hair of $E$. coli as sensory fiber, conjugation tube, or mating arm? Biochemical and Biophysical Research Communications 27, 674-680.

Jacob, A. E., Shapiro, J. A., Yamamoto, L., Smith, D. I., COHEN, S. N. \& BERG, D. (1977). Plasmids studied in Escherichia coli and other enteric bacteria. In DNA Insertion Elements, Plasmids and Episomes, pp. 607-638. Edited by A. I. Bukhari, J. A. Shapiro \& S. L. Adhya. Cold Spring Harbor, NY: Cold Spring Harbor Laboratory.

Khatoon, H. R., IYER, R. V. \& IYER, V. N. (1972). A new filamentous bacteriophage with sex factor specificity. Virology 48, 145-155.

Marvin, D. A. \& HoHN, B. (1969). Filamentous bacterial viruses. Bacteriological Reviews 33, 172-209.

Meynell, G. G. \& LaWN, A. M. (1968). Filamentous phages specific for the I sex factor. Nature, London 217, 1184-1186.

Novotny, C., KNIGHT, W. S. \& Brinton, C. C. (1968). Inhibition of bacterial conjugation by ribonucleic acid and deoxyribonucleic acid male-specific bacteriophages. Journal of Bacteriology 95, 314-326.

Silverman, P. M. \& Valentine, R. C. (1969). The RNA injection step of bacteriophage $\mathrm{f} 2$ infection. Journal of General Virology 4, 111-124.

Sranisich, V. A. (1974). The properties and host range of the male-specific bacteriophages of Pseudomonas aeruginosa. Journal of General Microbiology 84, 332-342.

SUN, T-P. \& Webster, R. E. (1986). fii, a bacterial locus required for filamentous phage infection and its relation to colicin-tolerant tolA and tolB. Journal of Bacteriology 165, 107-115. 
SUN, T-P. \& WeBster, R. E. (1987). Nucleotide sequence of a gene cluster involved in entry of $E$ colicins and single-stranded DNA of infecting filamentous bacteriophages into Escherichia coli. Journal of Bacteriology 169, 2667-2674.

Watanabe, T. (1964). Persistent infection with an RNA bacteriophage. Nikon Rinsho 22, 243-251.

Willetts, N. \& Wilkins, B. (1984). Processing of plasmid DNA during bacterial conjugation. Microbiological Reviews 48, 24-41.
Wolfson, J. S., Hooper, D. C., Swartz, M. N. \& MCHUGH, G. L. (1982). Antagonism of the B subunit of DNA gyrase eliminates plasmids pBR322 and pMG110 from Escherichia coli. Journal of Bacteriology 152, 338-344.

Worobec, E. A., Ashok, T. K., Hodges, R. S. \& PARANCHYCH, W. (1983). Localization of the major antigenic determinant of EDP208 pili at the Nterminus of the pilus protein. Journal of Bacteriology 153, 955-961. 